\title{
An account describing an operation for the bullet extraction from the middle of 17 th century Ottoman traveller Evliyâ Çelebi (1611-1682 AD)
}

\author{
Mehmet Turgut
}

Published online: 1 April 2010

(C) Springer-Verlag 2010

Evliyâ Çelebi (1611-1682), a famous Ottoman globetrotter, received an early training in the area of music and other arts in the Enderun of Topkapı Palace in Istanbul and spent some 40 years journeying throughout the extensive territory of the Ottoman empire covering North Africa and the Arab Peninsula in the south, Crimea and the Caucasus in the north, Iran in the east, and Hungary in the West (Fig. 1) $[2,3]$. As a result, he produced an invaluable source of historic and geographic knowledge about the events of the 17th century Ottoman Empire, called Seyahatname (meaning Book of Travels) divided into 10-volume narrative written in spoken language (Fig. 2). Although a vast majority of the descriptions in this book were written in an exaggerated manner in Ottoman-Turkish, his accounts are widely accepted as a useful guide for the sociocultural features of the middle of 17th century Ottoman Empire and European countries [3]. Unfortunately, there is no English translation of the entire work at present, although there are translations of some excerpts from the Seyahatname in different languages.

In the 7th volume of his Seyahatname, the Turkish traveller Evliyâ Çelebi recounts the journey of Austria in the year 1665 in a long chapter [1]. According to his anectodal travelogue, Evliyâ Çelebi visited the Hospital of Saint Stephan's Cathedral on the banks of the Danube in the city of Vienna as a member of an Ottoman embassy in 1665, after the Battle of Saint Gotthard between an Ottoman army under the command of Köprülü Fazıl Ahmed and an Habsburg army led by Raimondo Montecuccoli, Jean de

\section{Turgut $(\bowtie)$}

Department of Neurosurgery,

Adnan Menderes University School of Medicine,

Aydın, Turkey

e-mail: drmturgut@yahoo.com
Coligny-Saligny, Wolfgang Julius von Hohenlohe, Prince Leopold of Baden, and Georg Friedrich of Waldeck on the river Raab on August 1, 1664 [1-3, http://en.wikipedia.org/ wiki/Battle_of_Saint_Gotthard_(1664)]. The following extraordinary account taken from this volume gives an original description of the neurosurgical technique for bullet extraction from the intracranial cavity via "trephination" [1-3]:

A relative of the King, who had been wounded in his skull by a shotgun bullet near the ear in the Battle of Saint Gotthard, was brought to the hospital. ... I took a permission from the chief surgeon to observe the surgical intervention for bullet extraction. At first they put the patient to bed. The man's eyes was excessively swollen like plums of Mardin, ${ }^{1}$ and his nose like eggplants of Morea. $^{2}$ The chief surgeon took out everybody from the room and there were only the surgeon, his assistant and me in the glassed room...

The chief surgeon gave a cupful of saffron-like liquid to the wounded man and the man lost consciousness. A hide belt was tied encircling the unconscious man's head and an assistant kept his head firmly. The chief surgeon made a sharp cut at the skin of the forehead from ear to ear. When he elevated the skin of the head next to right ear, the head bone appeared as white in colour; and there was no blood in the surgical area. Then, he thrust an iron crank into the head bone and he removed a bone fragment; thus the brain became visible. ... The bullet was under the cranium next to the brain and the its membranes.

\footnotetext{
${ }^{1}$ A city name in Turkey, which was within Otoman territory in the middle of 17 th century.

${ }^{2}$ A peninsula name in Greece, which was within Otoman territory in the middle of 17 th century.
} 


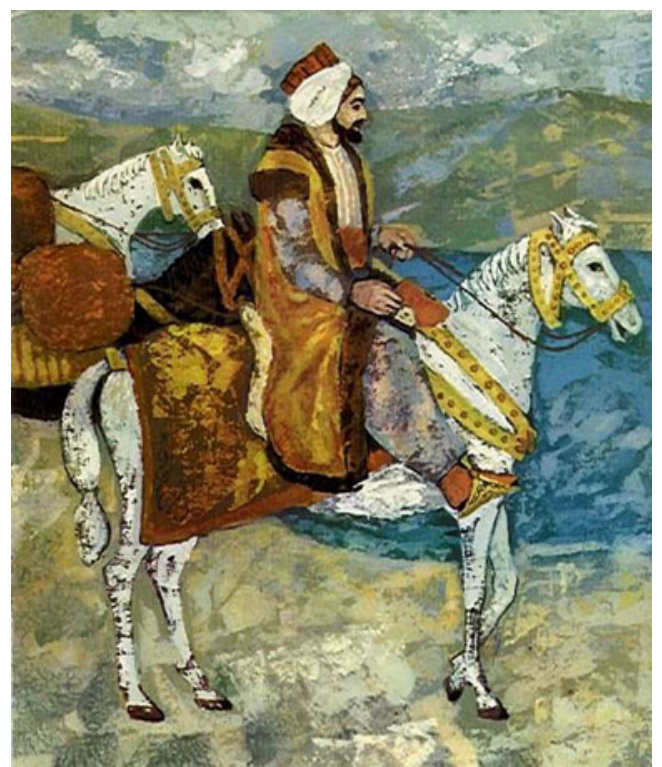

Fig. 1 A portrait of Evliyâ Çelebi on the horse by an anonymous painter, who reconstructed it according to written descriptions. Reproduced from www.mymerhaba.com with permission of $\mathrm{Mr}$. Zeydan Üstün (http://www.mymerhaba.com/Evliya-Çelebi-Travelerin-Turkey-138.html)

The chief surgeon invited me to come near man and observe the man's opened wound. I covered my mouth and nose with a large handkerchief and saw the wound of the man completely. ... The chief surgeon inquired about: "Why did you cover your nose and mouth with a handkerchief?". I answered as following: "I cough or sneeze during my observation; I am afraid of filling with air to the wound of the man during my respiration". The master surgeon admired my answer and he said: "You would have been a good surgeon if you had been a physician. ..."

The bullet under the cranium next to the brain was extracted with a tweezers. ... And he set the bones of the head of the man together and bring near the edges of the wound on the forehead. Then, the ants were brought next to the wound of the man; the chief surgeon cut out its body when the head of the ant caught the edges of the skin together. ... and a wick was put in the opening of the wound. The man was woken with the help of the fumigation in the room. ... On the 8th day the man could wander within the hospital, on the 15th day he returned to the King's court" [1-3].

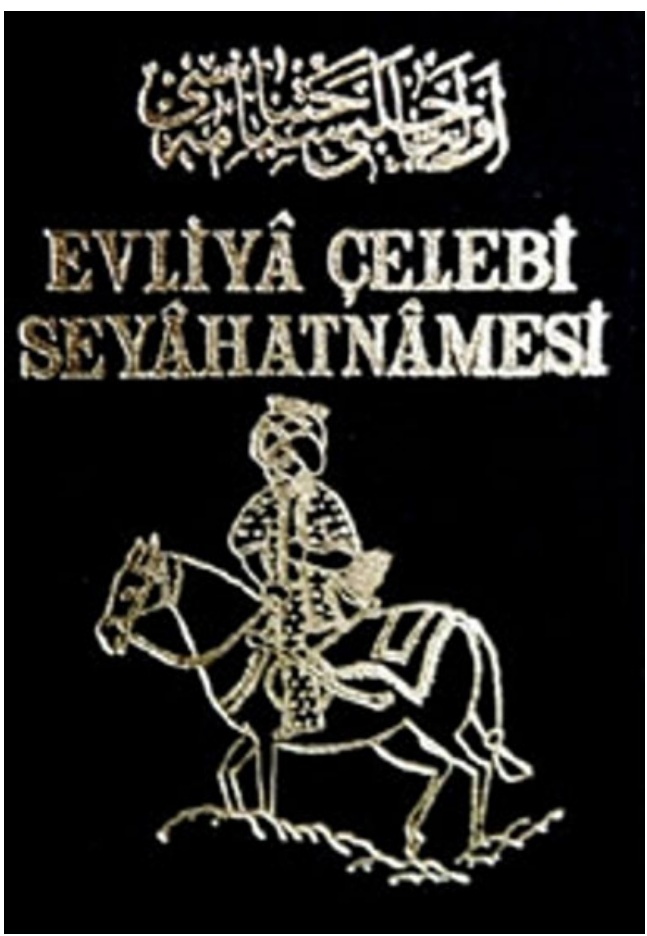

Fig. 2 The cover picture illustrates a sketch depicting title page from Evliyâ Çelebi's Seyahatname by an anonymous painter. Reproduced from www.chveneburi.net/tr/ with permission of Mr. Erdal Küçük (http:// www.chveneburi.net/tr/brochure.asp?bpgcid=24\&cat=y\&sbmt=y)

In the aforementioned account, Evliyâ Çelebi reported one of the earliest operations for the bullet extraction in that the surgeon of brain trephined over the bone, removed a bullet under the cranium, and placed a wick for drainage. In fact, he described his observation regarding the relationship between the Ottoman medical system and European medicine. Now, he is justified as a man of Istanbul, gentleman, reporter, entertainer, raconteur, and dervish in the 17th century Ottoman period. It is interesting to note that some of the surgical and aseptic techniques mentioned are still valid in the medical and scientific world.

\section{References}

1. Evliya Çelebi. Evliya Çelebi’s Book of Travels, vol. 7. Beyoğlu, İstanbul: Yapı Kredi Yayınları Ltd. Ști., 1996 (in Turkish)

2. Kökmen E (1972) A fantastic craniotomy: excerpt from the 17th century Turkish travelogue of Evliyâ Celebi. Case report. J Neurosurg 37:103-104

3. Mossensohn MS (2008) An Ottoman observer of central European surgery in the middle of the seventeenth century. Vesalius 14:4-7 